\title{
Butyricin 7423: a Bacteriocin Produced by Clostridium butyricum NCIB7423
}

\author{
By D. J. CLARKE AND J. G. MORRIS \\ Department of Botany and Microbiology, School of Biological Sciences, \\ University College of Wales, Aberystwyth $S Y 23{ }_{3} D A$
}

(Received 25 November 1975; revised 3 February 1976)

\begin{abstract}
SUMMARY
Butyricin 7423 is a trypsin-sensitive bacteriocin produced by Clostridium butyricum NCIB7423 and active against some other species of Clostridium. It has a bactericidal but non-lytic action on growing cultures of Clostridium pasteurianum. The primary action of butyricin 7423 appears to be at the cell membrane. Thus treatment of $C$. pasteurianum with an excess of butyricin altered the permeability of its cell membrane, allowing the release of several metabolites and ions. Efflux of rubidium ions from organisms preloaded with ${ }^{86} \mathrm{Rb}^{+}$was particularly rapid and extensive. The action of butyricin 7423 on Clostridium species seems to differ from that of other clostridocins, such as the boticins and perfringocin 28 , and more closely resembles the mode of action on susceptible (aerobic) organisms of bacteriocins such as staphylococcin $\mathrm{I} 580$ or colicins A, EI, I and K.
\end{abstract}

\section{INTRODUCTION}

Production of bacteriocins by species of Clostridium is not uncommon: boticins are formed by strains of Clostridium botulinum (Ellison \& Kautter, 1970; Lau, Hawirko \& Chow, I974); perfringocins by strains of Clostridium perfringens (Tubylewicz, I966; Mahony \& Butler, 197I); and other clostridocins are secreted by several unidentified nonpathogenic Clostridium species (Hongo et al., I968 a, b). Yet until recently, only the mode of action of perfringocin 28 had been studied in any detail, its bacteriolytic action being attributed either to inhibition of cell-wall synthesis or to removal of the existing wall (Mahony, Butler \& Lewis, 197I; Mahony, 1973).

We have recently discovered a bacteriocin produced by Clostridium butyricum $\mathrm{NCIB} 7423$ (and hence named butyricin 7423) whose action on Clostridium pasteurianum is readily distinguishable from that of perfringocin I I 105 (Clarke, Robson \& Morris, 1975). When secreted into the culture medium of the producer organism, butyricin 7423 is associated with carbohydrate, but it has been partially purified and shown to be a trypsin-sensitive, amphiphilic protein. Sodium dodecyl sulphate gel electrophoresis of purified butyricin 7423 revealed the existence of a polypeptide component of 32500 ( $\pm 10 \%$ ) daltons, which displayed the biological activity of butyricin 7423 in the absence of any detectable carbohydrate or lipid (Clarke et al., 1975). In this paper we report the limited spectrum of activity of purified butyricin 7423 and describe its bactericidal action on C. pasteurianum, which is attributed to damage wrought at the cell membrane. 


\section{METHODS}

Organisms. Clostridium butyricum NCIB7423 from the National Collection of Industrial Bacteria, Aberdeen, and Clostridium pasteurianum obtained from Mrs Winifred Ego, University of Hawaii, U.S.A., as ATCC6oI3, were maintained and cultured as previously described (Clarke et al., I975). Clostridium butyricum strains SAI, SAII, CNRZ528 and CNRZ53I were kindly provided by Mr J. Wolf, University of Leeds; Clostridium butyricum 855B, Clostridium caproicum CTII8, Clostridium sporogenes NCTC532, Clostridium tertium NCTC54I and Clostridium tyrobutyricum strains 62S and NCDOI 756 were kindly supplied by Dr T. A. Roberts, Meat Research Institute, Langford, Somerset; and all other species of Clostridium were supplied by the National Collection of Industrial Bacteria. Species of Pseudomonas were provided by our colleague Dr Muriel Rhodes-Roberts, and all other bacteria were either obtained from the National Collection of Industrial Bacteria or from our laboratory collection.

The Clostridium species were maintained at $4{ }^{\circ} \mathrm{C}$ as sporulated cultures grown anaerobically on slopes of reinforced clostridial medium (RCM; Oxoid) solidified with $\mathrm{I} \cdot 5 \%$ (w/v) agar (Difco-Bacto). Cultures were grown anaerobically at $37^{\circ} \mathrm{C}$ in RCM. Other bacteria were cultured, aerobically or anaerobically as necessary, in glucose $(0.5 \%, \mathrm{w} / \mathrm{v})$ nutrient broth (Oxoid).

Growth of $C$. pasteurianum. Cultures $(350 \mathrm{ml})$ in glucose minimal medium (Robson, Robson \& Morris, I974) were incubated anaerobically at $37^{\circ} \mathrm{C}$ in the fermenter vessel described by O'Brien \& Morris (1971).

Germination of $C$. pasteurianum spores. A washed suspension of spores of $C$. pasteurianum was prepared as described by Mackey \& Morris (197I) and heated at $70{ }^{\circ} \mathrm{C}$ for $5 \mathrm{~min}$. The heat-shocked spores were aseptically harvested by centrifuging for $10 \mathrm{~min}$ at $10000 \mathrm{~g}$ and $5{ }^{\circ} \mathrm{C}$, and were resuspended to $\mathrm{I} \cdot 8 \times 10^{8}$ spores $/ \mathrm{ml}$ in freshly prepared germination medium containing ( $\mathrm{g} / \mathrm{l}$ distilled water): dipicolinic acid, $5.0 ; \mathrm{CaCl}_{2} .6 \mathrm{H}_{2} \mathrm{O}, 3.6$; yeast extract (Oxoid), 3.0; casein hydrolysate (Sigma C050I), I0.0; glucose, 5.0 ; and L-cysteine hydrochloride, 0.5 ; all adjusted to $\mathrm{pH} 7.0$ with $\mathrm{KOH}$ and sterilized by autoclaving at $10 \mathrm{lbf}^{-2}$ for 20 min. Outgrowth medium was as described by Mackey \& Morris (1972). Changes in refractility of the spores and outgrowth of germling cells were observed by phase-contrast microscopy (Mackey \& Morris, 1972).

Measurement of growth. (i) Culture density was measured spectrophotometrically at $680 \mathrm{~nm}$ using a Pye-Unicam SP60o spectrophotometer (Pye-Unicam, Cambridge). (ii) Bacterial counts were performed microscopically using an improved Neubauer counting chamber. (iii) Viable counts were performed by the spread plate technique on RCM solidified with $\mathrm{r} \cdot 5 \%(\mathrm{w} / \mathrm{v})$ agar; suitable dilutions were prepared in glucose and agar-free RCM. In the case of $C$. pasteurianum the plates were incubated in anaerobic jars under an atmosphere of $\mathrm{H}_{2}-\mathrm{N}_{2}-\mathrm{CO}_{2}$ (I0:9: I, by vol.) at $37^{\circ} \mathrm{C}$ for 3 days before the colonies were counted.

Assay of butyricin 7423. The diffusion zone method described by Clarke et al. (1975) was used to measure the activity of butyricin preparations in arbitrary units (a.u.) per $\mathrm{ml}$.

Preparation of butyricin 7423 . Unlabelled preparations of butyricin 7423 were obtained and partially purified (to approx. 35 ka.u./mg protein) as previously described (Clarke et al., I975).

To obtain ${ }^{35} \mathrm{~S}$-labelled butyricin 7423, C. butyricum NCIB7423 was grown in the glucose minimal medium employed for $C$. pasteurianum, in which $\mathrm{MgSO}_{4}$ and $\mathrm{MnSO}_{4}$ were replaced by equimolar quantities of $\mathrm{MgCl}_{2}$ and $\mathrm{MnCl}_{2}$, and which was supplemented with (per litre): I.0 $\mathrm{mCi} \mathrm{Na}^{35} \mathrm{SO}_{4}\left(87 \mathrm{mCi} \mathrm{mmol}^{-1}\right)$, 30.0 $\mathrm{g} \mathrm{L}$-glutamic acid, I.75 $\mathrm{g}$ L-aspartic 
acid, $0.7 \mathrm{~g}$ L-phenylalanine, $0.7 \mathrm{~g}$ L-histidine, $4 . \mathrm{I} \mathrm{g}$ L-proline, $\mathrm{I} \cdot 5 \mathrm{~g}$ L-arginine and $3.7 \mathrm{~g}$ L-lysine. This medium, adjusted to $\mathrm{pH} 7 \cdot 0$ with $\mathrm{KOH}$, and freshly autoclaved at $15 \mathrm{lbf}^{-2} \mathrm{in}^{-2}$ for $15 \mathrm{~min}$, was inoculated with heat-activated $\left(60^{\circ} \mathrm{C}\right.$ for $\left.5 \mathrm{~min}\right)$ spores of $\mathrm{C}$. butyricum NCIB7423. The culture was incubated at $37{ }^{\circ} \mathrm{C}$ under an atmosphere of $\mathrm{N}_{2}-\mathrm{CO}_{2}(95: 5, \mathrm{v} / \mathrm{v})$ until early stationary phase, when the ${ }^{35} \mathrm{~S}$-labelled butyricin 7423 in the culture supernatant was concentrated and purified as previously described by Clarke et al. (I975).

Adsorption of butyricin 7423. (i) Unlabelled butyricin. When a culture of $C$. pasteurianum in glucose minimal medium, or of $C$. butyricum $\mathrm{NCIB}^{2} 423$ in the same medium supplemented with $5 \%(\mathrm{w} / \mathrm{v})$ casein hydrolysate (Sigma), had attained a density of about $2 \times 10^{7}$ organisms $/ \mathrm{ml}$, it was harvested by centrifuging ( $10000 \mathrm{~g}$ for $10 \mathrm{~min}$ at $5{ }^{\circ} \mathrm{C}$ ). The pellet was resuspended (to $6 \times 10^{7}$ organisms $/ \mathrm{ml}$ ) in the appropriate anaerobic growth medium (freshly autoclaved and reduced with a trace quantity of sodium dithionite), and the suspension stored at $0{ }^{\circ} \mathrm{C}$ under $\mathrm{N}_{2}-\mathrm{CO}_{2}(95: 5, \mathrm{v} / \mathrm{v})$ for no more than $30 \mathrm{~min}$, during which time a bacterial count was taken. Portions $(30 \mathrm{ml})$ of the suspension were pre-incubated at $37^{\circ} \mathrm{C}$ for $5 \mathrm{~min}$, and known amounts of butyricin were added, mixed immediately and continuously sparged with oxygen-free argon. Samples $(4 \mathrm{ml})$ were removed at $5 \mathrm{~min}$ intervals into ice-cold tubes which were centrifuged at $26000 \mathrm{~g}$ for I min at $2{ }^{\circ} \mathrm{C}$. Two I $\mathrm{ml} \mathrm{samples}$ of the resulting supernatant were removed and lyophilized (i) immediately and (ii) after addition of $0.2 \mathrm{mg}$ Triton X-roo. Each was resuspended in $0.3 \mathrm{ml} 50 \%(\mathrm{v} / \mathrm{v})$ ethanol, centrifuged for Io min at $20000 \mathrm{~g}$, and $0.1 \mathrm{ml}$ amounts of the supernatants were assayed for butyricin.

(ii) ${ }^{35}$ S-labelled butyricin. Fresh suspensions of organisms in growth media were prepared as above and exposed at $37{ }^{\circ} \mathrm{C}$ to known concentrations of ${ }^{35} \mathrm{~S}$-labelled butyricin. Samples ( $\mathrm{I} \mathrm{ml}$ ) were taken at $5 \mathrm{~min}$ intervals into ice-cold tubes and centrifuged at $26000 \mathrm{~g}$ for I min at $2{ }^{\circ} \mathrm{C}$. The supernatants were retained and the pellets resuspended in ice-cold growth medium ( $\mathrm{I} \mathrm{ml}$ ). (This sampling procedure was routinely completed in $80 \mathrm{~s}$.) After $50 \mathrm{~min}$ at $0{ }^{\circ} \mathrm{C}$, the suspensions were recentrifuged to yield 'terminal' pellet and 'second' supernatant fractions. The radioactivity was assayed in $0.1 \mathrm{ml}$ samples of the 'first' and 'second' supernatants and of the 'terminal' pellet (after suspension in $0.5 \mathrm{ml}$ of medium).

Measurement of DNA, RNA and protein synthesis. (i) By incorporation of radioactivelylabelled precursors. $\left[2-{ }^{14} \mathrm{C}\right]$ Thymine, $\left[2-{ }^{14} \mathrm{C}\right]$ uracil, or $\mathrm{L}-\left[\mathrm{U}-{ }^{14} \mathrm{C}\right]$ phenylalanine (each of Io $\mu \mathrm{Ci} \mu \mathrm{mol}^{-1}$ ) was supplied at Io mM final concentration to a culture of $C$. pasteurianum in its exponential phase of growth. Samples $(3 \mathrm{ml})$ of the culture were withdrawn at intervals, mixed with an equal volume of ice-cold, $10 \%(\mathrm{w} / \mathrm{v})$ trichloroacetic acid and allowed to stand at $0{ }^{\circ} \mathrm{C}$ for $90 \mathrm{~min}$. The suspensions were filtered through glass-fibre discs (Whatman, Grade GF/C, $2.5 \mathrm{~cm}$ diam) which were then washed with $30 \mathrm{ml} 5 \%$ trichloroacetic acid, dried, and their radioactivities measured.

(ii) By chemical assay. DNA was extracted and measured by the diphenylamine procedure of Burton (1956), and RNA was measured by the orcinol method (Herbert, Phipps \& Strange, 197I). Protein was extracted from pellets by digestion with $\mathrm{O} \cdot \mathrm{I} \mathrm{M}-\mathrm{NaOH}$ at $50{ }^{\circ} \mathrm{C}$ for $15 \mathrm{~min}$, and was estimated by the method of Lowry et al. (I95I).

Efflux of metabolites. Clostridium pasteurianum was grown in glucose minimal medium supplemented with $3 \mathrm{~mm}\left[8-{ }^{3} \mathrm{H}\right]$ adenine, $\left[2{ }^{14} \mathrm{C}\right]$ uracil, or $\left[2{ }^{14} \mathrm{C}\right]$ thymine (each of $0.3 \mathrm{mCi}$ $\mathrm{mmol}^{-1}$ ), or with $40 \mathrm{nCi} \mathrm{ml}^{-1}$ of [U-14C]-labelled hydrolysed protein $(46 \mathrm{mCi} /$ milliatom of carbon). Samples $(250 \mathrm{ml})$ of these cultures were harvested by centrifuging for $10 \mathrm{~min}$ at $20000 \mathrm{~g}$ and $4{ }^{\circ} \mathrm{C}$, the organisms were resuspended in $60 \mathrm{ml}$ (final vol.) of freshly autoclaved glucose minimal medium, and the suspensions sparged with oxygen-free argon for at least $5 \mathrm{~min}$ at $37^{\circ} \mathrm{C}$ prior to the addition of butyricin. Samples $(3 \mathrm{ml})$ were withdrawn at $5 \mathrm{~min}$ intervals into ice-cold tubes, and centrifuged for $\mathrm{I} \min$ at $26000 \mathrm{~g}$ and $2{ }^{\circ} \mathrm{C}$. Each 
supernatant was retained, and each pellet was resuspended in I $\mathrm{ml}$ of boiling water and held for Io min at $100{ }^{\circ} \mathrm{C}$. After cooling in ice, the suspension was recentrifuged to yield a final pellet and hot water extract. Samples (0.I ml) of the extracted pellet, first supernatant, and hot water extract, were dried on $2 \times 2 \mathrm{~cm}$ squares of filter paper (Whatman no. I) and their radioactivities were measured.

Efflux of ${ }^{86} \mathrm{Rb} \mathrm{b}^{+}$ions. Clostridium pasteurianum was loaded with ${ }^{86} \mathrm{Rb}^{+}$by growth in glucose minimal medium in which potassium phosphate buffer was replaced by an equimolar amount of sodium phosphate buffer $\mathrm{pH} \mathrm{7,} \mathrm{and} \mathrm{which} \mathrm{was} \mathrm{supplemented} \mathrm{with}$ $0.13 \mu \mathrm{Ci} \mathrm{ml}{ }^{-1}$ of ${ }^{86} \mathrm{RbCl}\left(0.35 \mathrm{mg} \mathrm{mCi}^{-1}\right)$. Samples (Io ml) of the late exponential-phase culture were harvested by anaerobic centrifugation at $8000 \mathrm{~g}$ for $10 \mathrm{~min}$ at room temperature, and the organisms were resuspended in a $\mathrm{N}_{2}-\mathrm{CO}_{2}(95: 5, \mathrm{v} / \mathrm{v})$ atmosphere in Io $\mathrm{ml}$ of $15 \%(\mathrm{w} / \mathrm{v})$ sucrose in $50 \mathrm{mM}$-sodium phosphate buffer, $\mathrm{pH} 7.0$. The suspension was sparged with oxygen-free argon for between 5 and 8 min at $37^{\circ} \mathrm{C}$ before adding butyricin. Samples $(2 \mathrm{ml})$ were taken at intervals and filtered through Millipore membranes $(0.45 \mu \mathrm{m}$ pore size). The separated organisms were washed with $10 \mathrm{ml}$ of $10 \%(\mathrm{w} / \mathrm{v})$ non-radioactive $\mathrm{RbCl}$, dried, and their radioactivities were measured.

Spectrophotometry. This was generally performed using a Pye-Unicam SPI 800 recording spectrophotometer.

Radioactivity measurements. Radioactivity was measured by scintillation counting with a Beckman LS-200B spectrometer (Beckman-RIIC, Glenrothes, Scotland). Aqueous samples (less than $0.5 \mathrm{ml}$ ) were assayed with negligible quenching in $10 \mathrm{ml}$ amounts of a mixture containing: $4 \mathrm{~g} \mathrm{2,5-diphenyloxazole} \mathrm{(PPO);} 500 \mathrm{ml}$ Triton X-I00; and toluene (to I litre). Dried squares of filter paper, glass-fibre discs and Millipore membranes were submerged in Io $\mathrm{ml}$ amounts of this mixture, or of a mixture containing $4.8 \mathrm{~g}$ PPO/litre toluene.

Chemicals. Triton X-IOo (scintillation grade) and Triton X-I oo containing approximately Io mol ethylene oxide/mol (employed for all purposes other than scintillation counting) were obtained from BDH. Trypsin (EC 3.4.4.4) of activity 4000 N.F. units/g was purchased from Hopkins \& Williams, Swansea. Radioactively labelled compounds were obtained from The Radiochemical Centre, Amersham, Buckinghamshire.

\section{RESULTS}

\section{Limited spectrum of activity of butyricin 7423}

Crude supernatants from late exponential-phase cultures of C. butyricum NCIB7423 inhibited growth of a number of diverse bacteria (including strains of Pseudomonas fluorescens, Flavobacterium devorans and Micrococcus denitrificans), but purified butyricin 7423 had a much more restricted spectrum of activity, only inhibiting certain species of Clostridium (Table I). Pre-incubation of the purified butyricin preparation (60 a.u./ml) with trypsin (30 min at $37^{\circ} \mathrm{C} ; \mathrm{pH} 7 \cdot 0 ; 8$ N.F. units of enzyme/ml) completely abolished its activity. Since $C$. pasteurianum was sensitive to inhibition by butyricin 7423 , it was employed as the indicator organism for routine assay of butyricin activity.

\section{Bactericidal action of butyricin 7423 on C. pasteurianum}

Addition of an excess of butyricin 7423 (IO a.u./10 7 organisms) to a culture of C. pasteurianum in its mid-exponential phase, quickly halted growth, but caused no decrease in the extinction of the culture. There was, however, rapid loss of viability, with over $99.9 \%$ of the organisms being killed within $60 \mathrm{~min}$. A concentration of 0.9 a.u. $/ \mathrm{Io}^{7}$ organisms was sufficient to cause complete inhibition of growth (Fig. I) and only when a large quantity of 


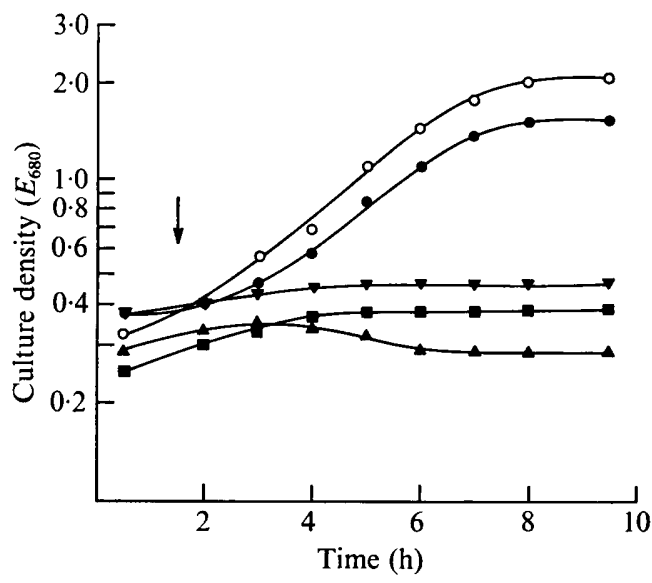

Fig. I

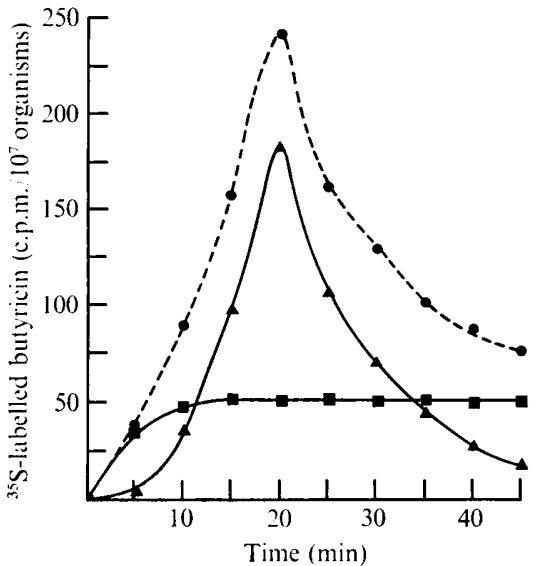

Fig. 2

Fig. I. Inhibition by butyricin 7423 of growth of $C$. pasteurianum on glucose minimal medium. An exponentially growing culture of $C$. pasteurianum was used to inoculate six freshly prepared $100 \mathrm{ml}$ portions of glucose minimal medium which were then incubated anaerobically at $37^{\circ} \mathrm{C}$. After approx. $60 \mathrm{~min}$ (arrowed), butyricin 7423 was added in the following concentrations (a.u./10 ${ }^{7}$ organisms): none or $0.22(0) ; 0.44(0) ; 0.90(\nabla) ; 17.20(\boldsymbol{⿴ 囗 ⿴ 囗 十 )}) ; 16.0(\Delta)$. Growth was followed by measurement of the extinction at $680 \mathrm{~nm}$.

Fig. 2. Adsorption of ${ }^{35} \mathrm{~S}-$ labelled butyricin 7423 by $C$. pasteurianum. The bacteria were suspended in growth medium (see Methods) to approx. $2 \times 10^{7}$ organisms $/ \mathrm{ml}$, and exposed at zero time to ${ }^{35}$ S-labelled butyricin (0.9 a.u./10 ${ }^{7}$ organisms; 470 c.p.m./a.u.). Radioactivity removed from the medium (O), recoverable from the organisms by washing with growth medium at $0^{\circ} \mathbf{C}(\boldsymbol{\Lambda})$, and irreversibly bound to the organisms ( $\square$ ), was assayed at intervals.

\section{Table I. Sensitivity to butyricin 7423 of some species of Clostridium}

Sensitivity to butyricin 7423 was assayed by the diffusion zone method (Clarke et al., 1975) and is expressed as a percentage of the sensitivity displayed by the standard assay organism Clostridium pasteurianum ATCC6013.

Butyricin sensitive strains

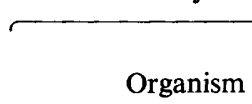

C. acetobutylicum NCIB6443

C. acetobutylicum $\mathrm{NCIB} 6444$

C. acetobutylicum NCIB6445

C. acetobutylicum NCIB8052

C. acetobutylicum $\mathrm{NCIB} 8653$

C. beijerinckii

$\mathrm{NCIB9362}$

C. bifermentans

C. butyricum

C. butyricum

C. butyricum

C. butyricum

C. butyricum

C. butyricum

C. caproicum

C. carbonei

C. pasteurianum

C. tyrobutyricum

C. tyrobutyricum

C. tyrobutyricum
Butyricin insensitive strains

\section{Relative} sensitivity $\%$

$\begin{array}{rll}64 \cdot \mathrm{I} & \text { C. } \text { butylicum } & \mathrm{NCIB9380} \\ 40 \cdot 0 & \text { C. pectinovorum } & \mathrm{NCIB} 8564 \\ 82 \cdot 4 & \text { C. putrefaciens } & \mathrm{NCIB9836} \\ 81 \cdot 6 & \text { C. } \text { sporogenes } & \mathrm{NCTC} 532 \\ 10 \mathrm{I} \cdot \mathrm{I} & \text { C. } \text { tertium } & \mathrm{NCTC} 54 \mathrm{I}\end{array}$

$60 \cdot 8$

$38 \cdot 9$

40.0

$58 \cdot 4$

$60 \cdot 8$

$92 \cdot 0$

46.0

$66 \cdot 6$

$53 \cdot 3$

$68 \cdot 8$

100.0

$5 \mathrm{I} \cdot 0$

80.0

$73 \cdot 3$ 


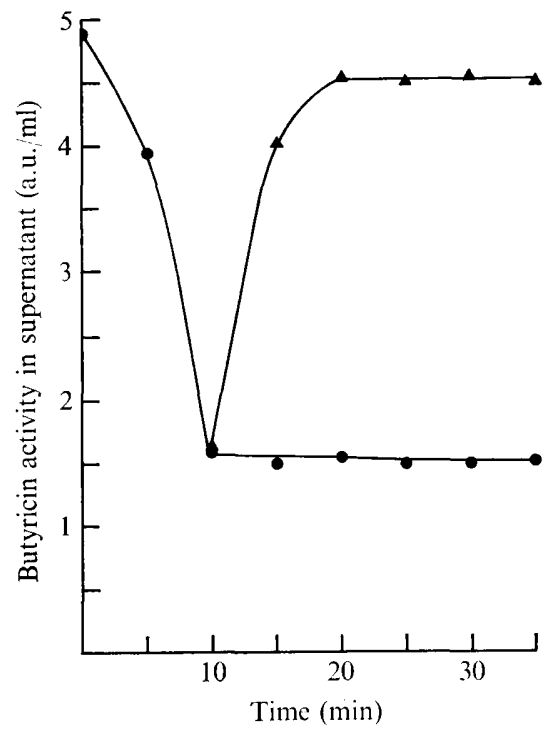

Fig. 3

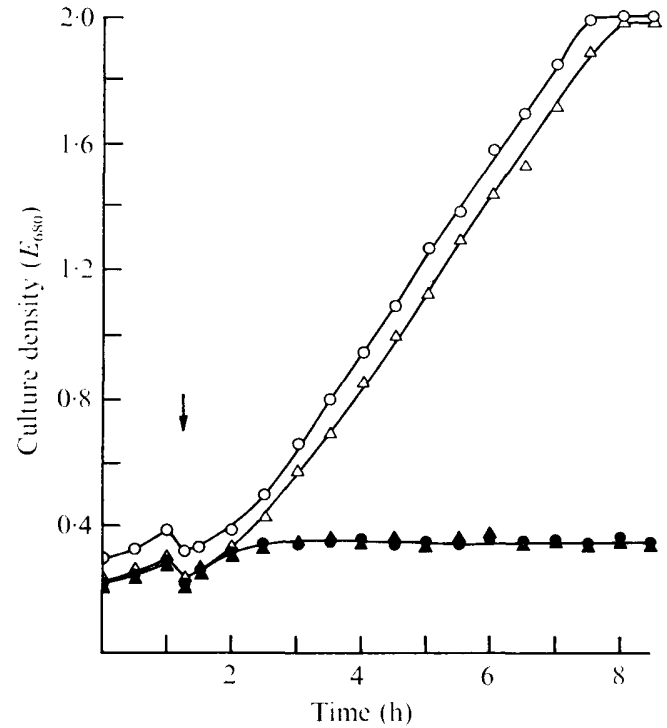

Fig. 4

Fig. 3. Adsorption of unlabelled butyricin 7423 by $C$. pasteurianum. Butyricin 7423 (0.9 a.u./10? organisms) was added at zero time to a suspension of $6 \times 10^{7}$ organisms $/ \mathrm{ml}$ in glucose minimal medium, kept anaerobic at $37^{\circ} \mathrm{C}$. Butyricin activity in the medium was assayed before ( $(0)$ and after $(\boldsymbol{\Delta})$ treatment of the medium with Triton X-Ioo.

Fig. 4. Inability of trypsin to reverse the action of butyricin 7423 on growing cultures of $C$. pasteurianum. Cultures of $C$. pasteurianum in glucose minimal medium were incubated anaerobically at $37^{\circ} \mathrm{C}$, and the following additions were made at that time indicated by the arrow: no addition,

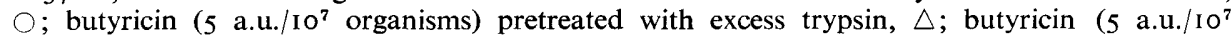
organisms),

butyricin ( $16 \mathrm{a}$ a. $/ \mathrm{IO}^{7}$ organisms) was added to a culture of low density in early exponential phase, was there any evidence of even slight bacterial lysis.

\section{Reversible and irreversible adsorption of butyricin 7423 to bacteria}

When ${ }^{35}$ S-labelled butyricin 7423 was introduced into a suspension of $C$. pasteurianum in glucose minimal medium at the minimum concentration capable of totally inhibiting growth (i.e. 0.9 a.u. $/ \mathrm{IO}^{7}$ organisms), the bacteriocin was progressively adsorbed (Fig. 2). Adsorption reached a maximum after I5 to $20 \mathrm{~min}$ at $37^{\circ} \mathrm{C}$ when about 25000 molecules of butyricin were bound to each organism. Progressive release of much of this bound butyricin then occurred, to leave about 5000 molecules per organism in the bound state.

The adsorption of unlabelled butyricin 7423 was studied by following the loss of butyricin activity from the supernatant of a suspension of $C$. pasteurianum in glucose minimal medium. The lower sensitivity of the biological assay for butyricin activity required that a bacterial suspension of greater density be employed in these experiments. Maximum adsorption of the bacteriocin was achieved more rapidly (in Io $\mathrm{min}$ ), but the more surprising finding was that there was no subsequent release of butyricin activity into the medium (Fig. 3). Treatment of the medium with Triton $\mathrm{X}$-Ioo revealed that, following maximum adsorption, rapid release of the bulk of the bound butyricin had indeed occurred, but that it had been desorbed in some 'latent' form capable of being restored to full activity by treatment with the non-ionic detergent (Fig. 3). 

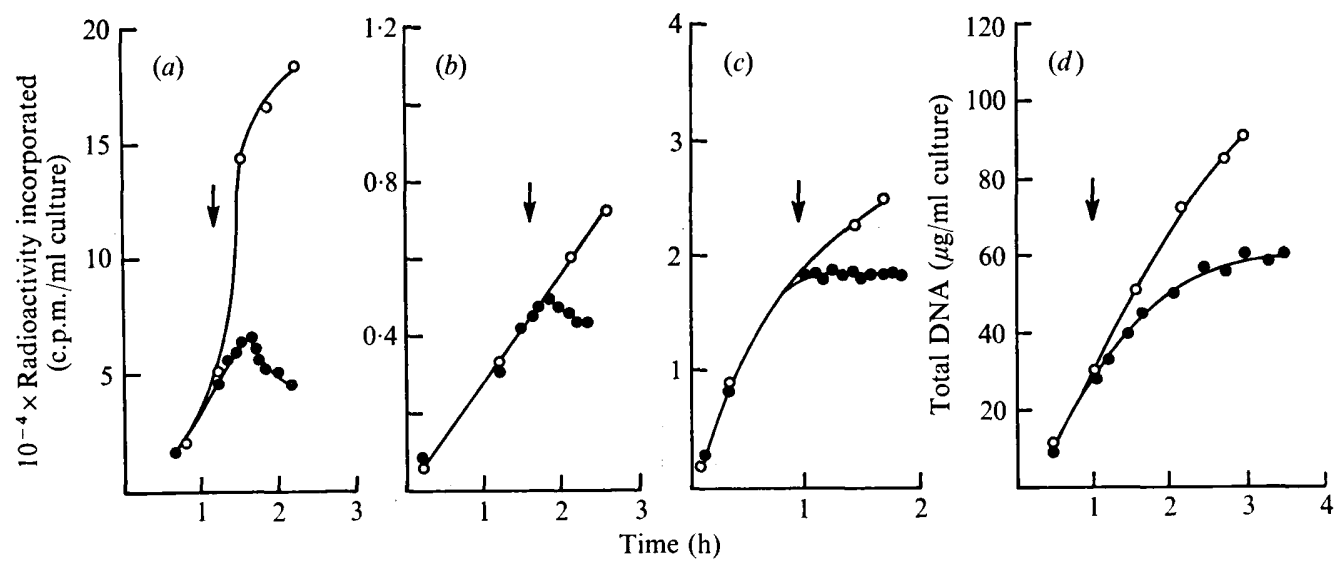

Fig. 5. Inhibition by butyricin 7423 of macromolecular synthesis in $C$. pasteurianum. The experimental procedures are described in Methods. Synthesis in exponential-phase cultures of $C$. pasteurianum was followed in the absence $(O)$ or presence $(\Theta)$ of butyricin $7423\left(3 \cdot 2\right.$ a.u./ $10^{7}$ organisms) added at that time indicated by the arrow. (a) RNA synthesis followed by incorporation of $\left[{ }^{2-14} \mathrm{C}\right]$ uracil. (b) Protein synthesis followed by incorporation of L-[U-14C]phenylalanine. (c) DNA synthesis followed by incorporation of $\left[2-{ }^{14} \mathrm{C}\right]$ thymine. $(d)$ DNA synthesis measured by chemical analysis of DNA content of the organism.

\section{Inability of trypsin to reverse butyricin action on growing C. pasteurianum}

Though butyricin 7423 was itself rapidly and totally inactivated by trypsin, addition of excess trypsin $\left(2 \mathrm{mg} \mathrm{ml}^{-1}\right)$ only I min after exposure of an exponential-phase culture of C. pasteurianum to butyricin ( 5 a.u./10 ${ }^{7}$ organisms), failed to 'rescue' the organisms from the lethal action of the bacteriocin (Fig. 4).

\section{Butyricin inhibition of DNA, RNA and protein biosynthesis}

When the biosynthesis of DNA, RNA and protein in growing cultures of $C$. pasteurianum was followed by incorporating suitable radioactively-labelled precursors, rapid inhibition of all three processes was observed on addition to the culture of a lethal concentration of butyricin 7423 (3.2 a.u. $/ 10^{7}$ organisms). For example, incorporation of $\left[2^{-14} \mathrm{C}\right]$ thymine, followed as an indicator of DNA synthesis, ceased within $5 \mathrm{~min}$ of exposure of the organisms to butyricin (Fig. 5 c). RNA synthesis, measured by $\left[2-{ }^{14} \mathrm{C}\right]$ uracil incorporation, and protein synthesis, followed by incorporation of L-[U-14 C]phenylalanine, both halted within Io to I5 min (Figs. $5 a$ and $b$ ). Yet, when the increase in DNA, RNA and protein in the culture was followed by chemical analysis, it was found that synthesis of all three species of macromolecule continued for up to $\mathrm{I} h$ after addition of the butyricin, as illustrated for DNA synthesis in Fig. $5(d)$.

\section{Butyricin-provoked efflux of cell metabolites}

Substantial amounts of low molecular weight compounds with pronounced extinction at $260 \mathrm{~nm}$ were released into the medium when cultures of $C$. pasteurianum were treated with a high concentration of butyricin 7423 ( $>10$ a.u./10 $0^{7}$ organisms). There was a consequent marked rise in the $260 \mathrm{~nm}$ extinction of the culture supernatant some 15 min after addition of the bacteriocin. Preloading of the organism with radioactively-labelled adenine, uracil, thymine or amino acids demonstrated that treatment with excess butyricin in each case provoked efflux of radioactively-labelled substances. Efflux was progressively more rapid 


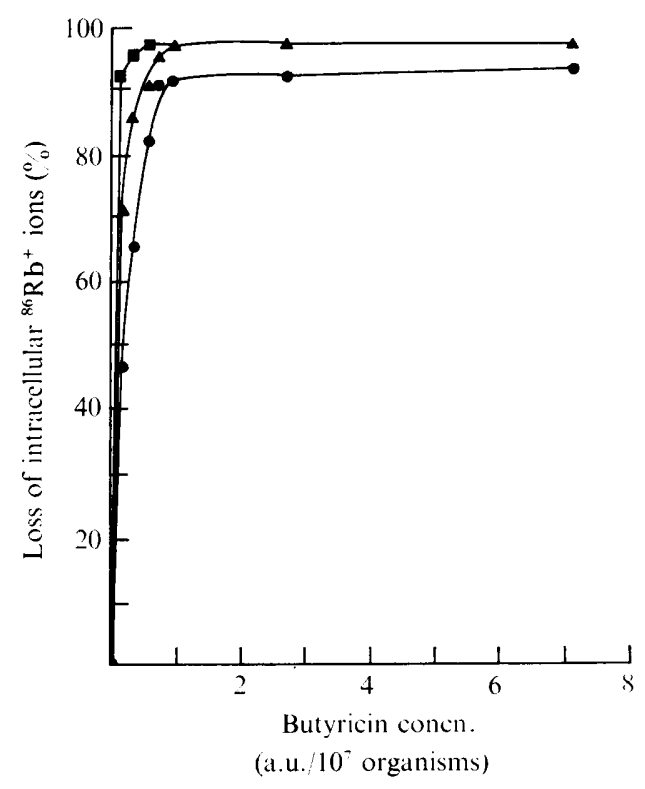

Fig. 6. Rapid ${ }^{86} \mathrm{Rb}^{+}$efflux from $C$. pasteurianum on treatment with low concentrations of butyricin 7423. Bacteria preloaded with ${ }^{86} \mathrm{Rb}^{+}$were resuspended anaerobically at $37^{\circ} \mathrm{C}$ in $\mathrm{I} 5 \%(\mathrm{w} / \mathrm{v})$ sucrose in $50 \mathrm{mM}$-sodium phosphate buffer, $\mathrm{pH} 7 \cdot 0$. After 5 to 8 min pre-incubation, a known concentration of butyricin 7423 was added, and the radioactivity of the organisms was measured after I min $(\boldsymbol{\theta})$, $2 \min (\Delta)$ and $4 \min (\boldsymbol{\square})$.

and extensive as the butyricin concentration was increased: it was not significant at low though still lethal concentrations, e.g. $\mathrm{I}^{\cdot} 5$ a.u. $/ \mathrm{IO}^{7}$ organisms. In no case was there any evidence of significant cell lysis in the suspension or of degradation of intracellular macromolecules (at least within the 60 min duration of these experiments).

\section{Butyricin-provoked efflux of ${ }^{86} \mathrm{R} \mathrm{b}^{+}$ions}

Exposure to butyricin 7423 caused immediate and very rapid loss of rubidium ions from ${ }^{86} \mathrm{Rb}^{+}$-preloaded cells of $C$. pasteurianum suspended in 50 mM-sodium phosphate buffer, $\mathrm{pH} 7 \cdot 0$, fortified with $15 \%$ (w/v) sucrose to obviate any contribution from cell lysis (Fig. 6). Again, the greater the concentration of butyricin, the more rapid was the observed efflux of ${ }^{86} \mathrm{Rb}^{+}$, but the effect was now pronounced even when very low concentrations of butyricin were employed. Organisms exposed to more than 0.7 a.u. butyricin/10 ${ }^{7}$ bacteria lost more than $90 \%$ of their initial content of rubidium ions within $60 \mathrm{~s}$ (Fig. 6).

\section{DISCUSSION}

Bacteriocins produced by Gram-positive organisms generally have no effect on Gramnegative bacteria, but may have a wider intergeneric spectrum of activity than is usual in the case of bacteriocins produced by Gram-negative organisms (Hamon \& Peron, 1963; Jetten \& Vogels, 1972; Bottone, Allerhand \& Pisano, 1974). Butyricin 7423 is therefore somewhat unusual in that its action on Gram-positive organisms is apparently limited to some species of Clostridium. Some of the Clostridium species found to be naturally resistant to butyricin 7423 are proteolytic and could owe their resistance to destruction of the bacteriocin, as was 
proposed for proteolytic strains of $C$. botulinum found to be resistant to boticin E (Anastasio, Soucheck \& Sugiyama, I97I). It is unlikely, however, that the butyricin resistance of some other strains, e.g. C. butylicum NCIB9380, can be so simply explained.

Since butyricin 7423 has a propensity for non-specific adsorption to certain surfaces, e.g. cellulose (Clarke et al., I975), it was pleasing to find a reproducible pattern in the kinetics of adsorption of the bacteriocin to cells of $C$. pasteurianum, with subsequent desorption leaving a relatively constant amount of butyricin firmly attached to the organism (Fig. 2). It was particularly interesting that the desorbed butyricin was returned to the medium in an inactive state. Its reactivation by treatment with Triton X-Ioo suggests that this might be some multimeric aggregate or, and perhaps more likely, a complex of butyricin with material derived from the cell envelope of $C$. pasteurianum. In contrast, butyricin 7423 is secreted in an active form by its producer organism $C$. butyricum $\mathrm{NCIB}_{423}$ (Clarke et al., 1975). The pattern of its adsorption suggests the existence of at least two classes of butyricin receptor sites, namely a number of irreversible binding sites supplemented by a larger number of reversible binding sites. Further studies of the kinetics of butyricin adsorption, and of the nature and location of the butyricin receptor sites will have to be undertaken with a labelled butyricin 7423 of higher specific radioactivity than the ${ }^{35} \mathrm{~S}$-labelled preparation used in the present investigation, e.g. with ${ }^{125} \mathrm{I}$-labelled butyricin.

The apparent inability of trypsin to reverse butyricin action on growing cultures of C. pasteurianum was not surprising: this is quite a common feature of bacteriocins from Gram-positive organisms, e.g. boticin E (Ellison \& Kautter, I970), perfringocin 28 (Mahony, Butler \& Lewis, I97I) or staphylococcin 1580 (Jetten \& Vogels, I974), though the lethal action of enterocin EIA on Streptococcus faecium could be prevented by trypsin treatment within 2 to $3 \mathrm{~min}$ of exposure to the bacteriocin (Kramer \& Brandis, 1975). Reversal of bacteriocin action by trypsin is much more common in bacteriocins acting on Gramnegative organisms, e.g. colicins, whose action is mediated in two sequential stages. In stage I, no detectable damage occurs and the cells can be 'rescued' by treatment with trypsin. In stage 2 , physiological damage is observed and the organisms can no longer be rescued by trypsin. The transition from stage $I$ to stage 2 is influenced by several factors (Holland, 1975) and probably requires expenditure of energy (Jetten \& Jetten, 1975; Okamoto, 1975). Though it is tempting to suppose that the amphiphilic nature of the butyricin molecule and the existence of only a single cell membrane in the Gram-positive organism facilitate the more rapid formation of a trypsin-irreversible, lethal complex (equivalent to complex 2 in colicin action), it will be interesting to see whether a lethal butyricin complex may only be formed with cells of $C$. pasteurianum whose membranes are 'energized'. Furthermore, before a trypsin rescuable stage can be entirely ruled out, more rigorous investigations will have to be undertaken using washed suspensions of C. pasteurianum treated with lower concentrations of butyricin than the 5 a.u./10 ${ }^{7}$ organisms employed in the experiments represented in Fig. 4.

Butyricin 7423 differs from perfringocin 28 in its non-lytic bactericidal action and its inhibition of DNA, RNA and protein biosynthesis (cf. Mahony, Butler \& Lewis, I97I). Evidence of butyricin's action on the cell membrane of $C$. pasteurianum was provided by the butyricin-provoked efflux of ${ }^{86} \mathrm{Rb}^{+}$. Flux of ${ }^{86} \mathrm{Rb}^{+}$has been much used as an indicator of the fate of $\mathrm{K}^{+}$ions in bacteria since transport of $\mathrm{K}^{+}$and $\mathrm{Rb}^{+}$is generally competitive (Wendt, I970); and leakage of intracellular $\mathrm{K}^{+}$has been regarded as one of the first signs of membrane damage (Lambert \& Hammond, 1973). In this respect, butyricin 7423 resembles several other bacteriocins that act at the cell membrane and cause rapid efflux of ${ }^{86} \mathrm{Rb}^{+}$, e.g. colicins A, EI, I and K (Fields \& Luria, I969; Holland, I975), staphylococcin 
I 580 (Jetten \& Vogels, I972, 1974), Challis streptocin (Schlegel \& Slade, 1974) and enterocin EIA (Kramer \& Brandis, I975).

Further studies of the effect of butyricin 7423 on uptake and release of substrates and ions by $C$. pasteurianum are now being undertaken in order to determine the nature and extent of damage to membrane functions that is wrought by this bacteriocin.

We are grateful to the Science Research Council for the Research Studentship held by D.J.C.

\section{REFERENCES}

Anastasio, K. L., Soucheck, J. A. \& SugiYama, H. (1971). Boticinogeny and actions of the bacteriocin. Journal of Bacteriology 107, I43-I49.

Bottone, E., Allerhand, J. \& Pisano, M. A. (1974). Effects of a bacteriocin produced by Streptococcus faecalis var. zymogenes $\left(\mathrm{EI}_{\mathrm{I}}\right)$ on susceptible micro-organisms. Antonie van Leeuwenhoek 40, 385-392.

BurTON, K. (1956). A study of the conditions and mechanisms of the diphenylamine reaction for the colorimetric estimation of deoxyribonucleic acid. Biochemical Journal 62, 315-322.

Clarke, J. D., Robson, R. M. \& Morris, J. G. (1975). Purification of two Clostridium bacteriocins by procedures appropriate to hydrophobic proteins. Antimicrobial Agents and Chemotherapy 7, 256-264.

Ellison, J. S. \& KaUtTer, J. A. (1970). Purification and some properties of two boticins. Journal of Bacteriology 104, 19-26.

FieLDS, K. L. \& LURIA, S. E. (1969). Effects of colicins EI and K on transport systems. Journal of Bacteriology 97, 57-63.

HAMON, Y. \& PERON, Y. (I963). Quelques remarques sur les bactériocines produites par les microbes Gram positifs. Comptes rendus hebdomadaires des séances del'Académie des sciences. Series D. Sciences Naturelles 257, I I 9 I-I I 93.

Herbert, D., Phipps, P. J. \& Strange, R. E. (I97I). Chemical analysis of microbial cells. In Methods in Microbiology, vol. 5B, pp. 316-344. Edited by J. R. Norris and D. W. Ribbons. London and New York: Academic.

Holland, I. B. (1975). Physiology of colicin action. In Advances in Microbial Physiology, vol. 12, pp. 55-139. Edited by A. H. Rose and D. W. Tempest. London and New York: Academic.

hongo, M., Murata, A., Kono, K. \& Kato, F. (1968a). Lysogeny and bacteriocinogeny in strains of Clostridium species. Agricultural and Biological Chemistry (Tokyo) 32, 27-33.

Hongo, M., Murata, A., Ogata, S., Kono, K. \& Kato, F. (I968b). Characterization of a temperate phage and four bacteriocins produced by nonpathogenic Clostridium species. Agricultural and Biological Chemistry (Tokyo) 32, 773-780.

Jetten, A. M. \& JetTen, M. E. R. (1975). Energy requirement for the initiation of colicin action in Escherichia coli. Biochimica et biophysica acta 387, 12-22.

Jetten, A. M. \& Vogels, G. P. (1972). Nature and properties of a Staphylococcus epidermidis bacteriocin. Journal of Bacteriology 112, 243-252.

JetTEN, A. M. \& Vogels, G. P. (1974). Characteristics of the killing effect of a Staphylococcus epidermidis bacteriocin. Antonie van Leeuwenhoek 40, I77-183.

Kramer, J. \& Brandis, H. (I975). Mode of action of two Streptococcus faecium bacteriocins. Antimicrobial Agents and Chemotherapy 7, II 7-I20.

LAMBERT, P. A. \& HAMmond, S. M. (1973). Potassium fluxes. First indications of membrane damage in micro-organisms. Biochemical and Biophysical Research Communications 54, 796-799.

LaU, A. H. S., Hawirko, R. Z. \& ChOW, C. T. (1974). Purification and properties of boticin P produced by Clostridium botulinum. Canadian Journal of Microbiology 20, 385-390.

Lowry, O. H., Rosebrough, N. J., FarR, A. L. \& Randall, R. J. (I95I). Protein measurement with the Folin phenol reagent. Journal of Biological Chemistry 193, 265-275.

MACKEY, B. M. \& MORRIS, J. G. (I97I). Ultrastructural changes during sporulation of Clostridium pasteurianum. Journal of General Microbiology 66, I-13.

MACKEY, B. M. \& MORRIS, J. G. (1972). Calcium dipicolinate-provoked germination and the outgrowth of spores of Clostridium pasteurianum. Journal of General Microbiology 73, 315-324.

MAHONY, D. E. (1973). Antibiotic sensitivity of Clostridium perfringens and L-forms of Clostridium perfringens induced by bacteriocin. Canadian Journal of Microbiology 19, 735-739.

MAHONY, D. E. \& BUTLER, M. E. (197I). Bacteriocins of Clostridium perfringens. I. Isolation and preliminary studies. Canadian Journal of Microbiology 17, I-6.

MahonY, D. E., ButLer, M. E. \& Lewis, R. G. (I97I). Bacteriocins of Clostridium perfringens. 2. Studies on mode of action. Canadian Journal of Microbiology 17, I435-I 442.

O'Brien, R. W. \& MorRIs, J. G. (197I). Oxygen and the growth and metabolism of Clostridium acetobutylicum. Journal of General Microbiology 68, 307-318. 
Oкамото, K. (1975). Requirement of heat and metabolic energy for the expression of inhibitory action of colicin K. Biochimica et biophysica acta 389, 370-379.

Robson, R. L., Robson, R. M. \& MorRIs, J. G. (1974). The biosynthesis of granulose by Clostridium pasteurianum. Biochemical Journal 144, 503-51 I.

SCHLEGEL, R. \& SLADE, H. D. (1974). Alteration of macromolecular synthesis and membrane permeability by a Streptococcus sanguis bacteriocin. Journal of General Microbiology 81, 275-277.

TUBYLEwICZ, H. (1966). Experimental studies on bacteriocinogeneity in Clostridium perfringens Type A. Bulletin de L'Académie polonaise des sciences. Série des Sciences biologiques 14, 3I-36.

WENDT, L. (1970). Mechanism of colicin action: early events. Journal of Bacteriology 104, I 236-I $24 \mathrm{I}$. 